Pobrane z czasopisma Annales H - Oeconomia http://oeconomia.annales.umcs.pl Data: 26/04/2023 13:59:51

DOI:10.17951/h.2018.52.6.25-35

\begin{tabular}{lcl}
\hline & A N N A L E S \\
UNIVERSITATIS & MARIAE C URIE-S KŁODOWSKA \\
LUBLIN - POLONIA & SECTIO H \\
VOL. LII, 6 & Warsaw School of Economics
\end{tabular}

PAWEŁ DEC

ORCID ID: https://orcid.org/0000-0001-8460-2591

pawel.dec@sgh.waw.pl

PIOTR MASIUKIEWICZ

ORCID ID: https://orcid.org/0000-0003-0686-5024

piotr.masiukiewicz@wp.pl

\title{
Model of Institutional Protection Scheme in Polish Cooperative Banks
}

Model systemu ochrony instytucjonalnej (IPS) w polskich bankach spółdzielczych

Keywords: cooperative bank; financial safety; liquidity; protection scheme; risk

Słowa kluczowe: bank spółdzielczy; bezpieczeństwo finansowe; płynność; model ochrony; ryzyko

JEL code: G21; G32; G33

\section{Introduction}

At some stage of the fairly dynamic development of cooperative banks, threats appeared that must be neutralized by organizations selected from the cooperative banking sector in Poland. Institutional protection systems were established in two associations of national cooperative banks as cooperatives managing the Institutional Protection Scheme (IPS). The Polish cooperative banking sector was in need of such a solution, and the EU directive, by introducing appropriate provisions under the CRD IV/CRR package, undoubtedly accelerated the implementation of this liquidity risk management concept. It should be emphasized that the adopted model of self-control 
of the sector is important for the effective operation of IPS. The protection system is not an external supervisory institution but a cooperative whose members are individual banks, while simultaneously being a separate institution from the associating bank which facilitates the exercise of the supervisory function without fear of yielding to external pressure. Furthermore, the system ensures greater transparency of cooperative associations. The trust among the participants is also based on quantifying the level of security of all who participate in the system. Unfortunately, some cooperative banks did not join this system. The main aim of this paper is to highlight the need for the functioning of institutional protection systems in cooperative banks. The thesis of the article is as follows: the IPS system significantly improves the security of associations of cooperative banks and individual banks, though it is necessary to cover all cooperative banking with this system. This article uses the following research methods: analysis of literature, legal acts, statistical data and case study.

\section{The IPS system against the background of the financial security system}

The foundations of the financial safety net were built in the European Union, and national networks were established in member countries. The coordination and cooperation of individual elements of the pan-European network is important, yet this has sometimes failed to materialize during the recent subprime financial crisis [The First Global Crisis..., 2008]. After the financial crisis, several institutional changes were introduced in this area. In the light of the lack of solutions identified at the EU level in terms of deposit guarantee, crisis management and restructuring activities, Member States are responsible for the stability of their financial systems and bear the consequences of possible crisis situations [Masiukiewicz, 2014]. The functioning of an efficient financial safety network is important in Poland, because there is a large network of cooperative banks and SKOK. The financial security network can be defined as: all legal regulations and self-regulation aimed at ensuring financial stability and protecting the interests of market participants using financial intermediaries, as well as all institutions responsible for controlling compliance with these regulations and self-regulation [Iwanicz-Drozdowska, 2008].

The Polish financial security system is well organized. It consists of the: Financial Stability Committee (KSF), Ministry of Finance, Polish Financial Supervision Authority (KNF), National Bank of Poland (NBP), Bank Guarantee Fund (BFG), insurance companies and compensation on the insurance and capital market, associating banks that obligatorily associate with co-operative banks, and the National Association of Credit Unions. Each of these institutions has statutory tasks [Masiukiewicz, 2014]. The institutional system of financial security is illustrated in Figure 1. A particularly important coordinating role in the security system is fulfilled by the new body, the KSF. The Committee is chaired by the Minister of Finance. KSF members, to strengthen international cooperation to maintain financial stability, may conclude agreements with 
institutions implementing tasks in this field in the countries of the European Economic Area (EEA), the European Central Bank, central banks that are part of the European System of Central Banks, and finance ministers and financial market surveillance authorities in the EEA countries [Masiukiewicz, 2013].

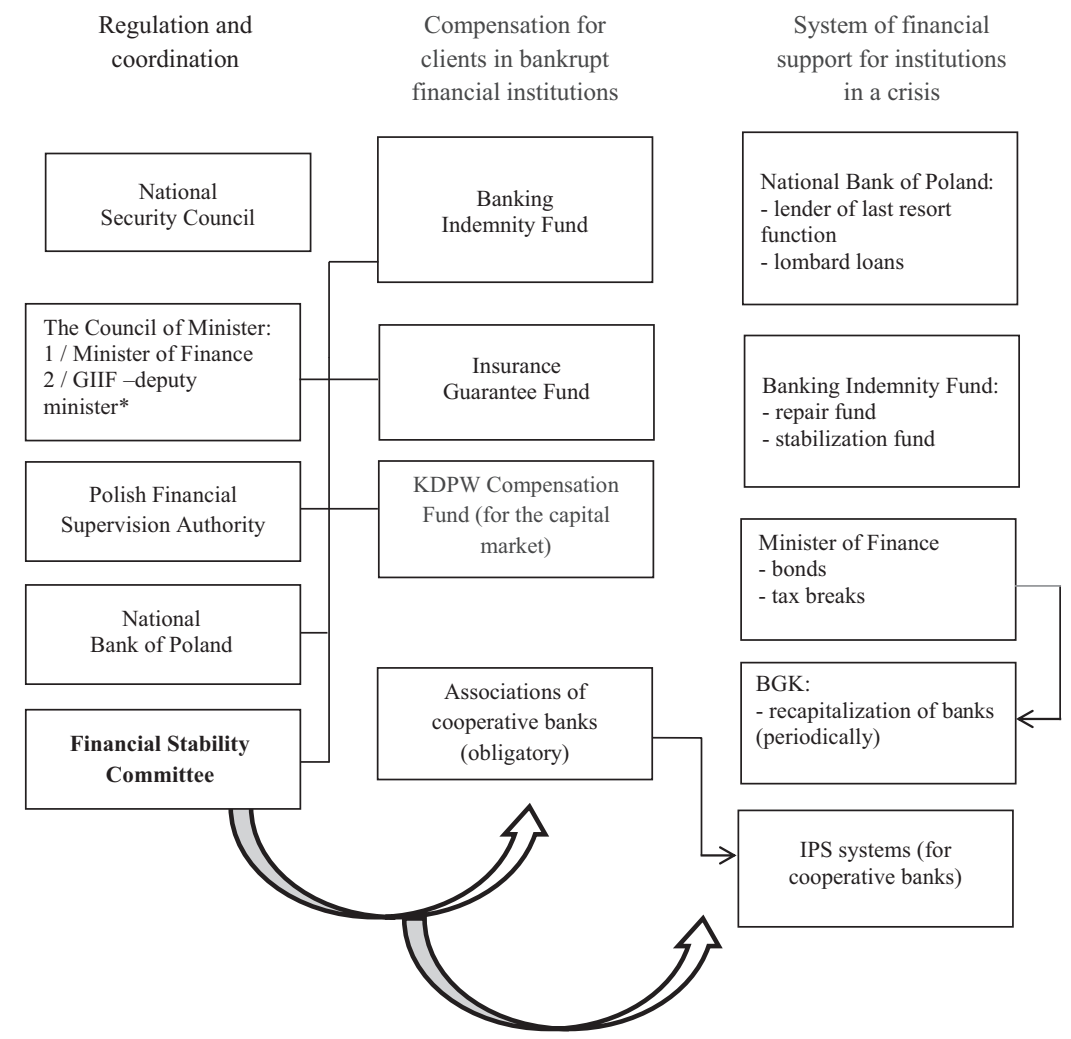

Figure 1. Institutional system of financial security in Poland

\footnotetext{
*General Inspector of Financial Information - deputy minister of finance responsible for counteracting money laundering and financing of terrorism

Source: Authors' own study.
}

An important change in the European Union's supervisory architecture is the establishment of a new macro-prudential supervision body, i.e. the European Systemic Risk Board, as well as the initiation of stress tests in large banks. Stress tests in the Polish banking system are conducted regularly by the KNF and the NDP [Dec, Masiukiewicz, 2012]. According to the CRD directive, banks in EU countries are able to create IPS systems, whose systems protect banks and guarantee their liquidity and solvency to avoid bankruptcy. Relating to the EC adoption of the CRD IV regulatory package, banks participating in IPS systems have obtained additional regulatory 
privileges [Koleśnik, 2013; Rolski, 2015; Piechocka-Kałużna, 2017]. The EU CRR Regulation provided for two security models for cooperative banks:

- creation of an integrated association;

- introduction of the IPS protection system.

Security systems are a form of cooperation between cooperative banks that have proven themselves over the years in Western European countries. An example is Germany, in which the IPS has existed since the 1930s; throughout the entire period of its operation, it ensured security for cooperative banks which did not have to use state aid. Most groups of cooperative banks in Western Europe have IPSs. The high risk and several bankruptcies of cooperative banks in the 1990s resulted in the introduction of a special law on the restructuring of cooperative banks and the launch of financial assistance for the restructuring and merger of banks (Table 1).

Table 1. Forms and scope of assistance for cooperative banks in the years 1995-2018

\begin{tabular}{|c|c|c|c|}
\hline No. & Entity providing assistance & Form and scope of assistance & Status \\
\hline 1 & NBP & A promissory note loan to maintain liquidity. & expired \\
\hline 2 & NBP & $\begin{array}{l}\text { Temporary exemption from the transfer of mandatory } \\
\text { reserves. }\end{array}$ & expired \\
\hline 3 & Minister of Finance & Temporary income tax exemption. & expired \\
\hline 4 & Minister of Finance & $\begin{array}{l}10 \text {-year restructuring bonds (subsidy) for the } \\
\text { restructuring of loans in cooperative banks. }\end{array}$ & expired \\
\hline 5 & BFG & $\begin{array}{l}\text { Loans for the implementation of remedial } \\
\text { programmes and combining cooperative banks. }\end{array}$ & functioning \\
\hline 6 & FAPA & Support for repair processes. & expired \\
\hline 7 & $\begin{array}{l}\text { Banks associating } \\
\text { cooperative banks }\end{array}$ & Mutual assistance funds - to maintain liquidity. & expired \\
\hline 8 & IPS systems & Liquidity assistance, restructuring loans - from 2017. & functioning \\
\hline
\end{tabular}

Source: Authors' own study.

Recent years have been characterized by higher risk in cooperative banks than commercial banks and their lower effectiveness (Table 2). Particularly worrying is the high C/I ratio and high write-offs for specific provisions (i.e. for covering lost loans). On the other hand, the high dynamics of net profit should be positively assessed.

Table 2. Risk in cooperative banks in 2017

\begin{tabular}{|c|l|c|c|}
\hline No. & \multicolumn{1}{|c|}{ Assessment meter/increase on the previous year } & Commercial banks & Cooperative banks \\
\hline 1 & Increase in assets & $3.4 \%$ & $7.9 \%$ \\
2 & Decrease in employment & $7.5 \%$ & $1.0 \%$ \\
3 & Tier 1 capital ratio & 17.3 & 16.3 \\
4 & Net financial result - increase & $-3.5 \%$ & $25.4 \%$ \\
5 & Write-downs and provisions - increase & $3.3 \%$ & $24.1 \%$ \\
6 & Cost to income ratio (C/I) & 54.5 & 65.6 \\
7 & ROE indicator & 6.9 & 6.0 \\
\hline
\end{tabular}

Source: Raport o sytuacji banków w 2017 r., KNF, Warszawa 2018. 
In 2017, 34 cooperative banks implemented repair programmes [Ochocki, 2018]. In Poland, based on EU directives, the parliament passed a new law on BFG and orderly bank liquidation, which implements the EU recovery and resolution regime. As a result of the above regulations and KNF resolutions, two IPS systems operate for cooperative banks, organized in the form of a cooperative: the Cooperative IPS Protection System for the association of the Cooperative Banking Group and Cooperative of the Association System of the Association of Bank Polskiej Spółdzielczości.

\section{Benefits and barriers of the system}

The cooperative banking sector needed to implement such a solution, and the EU regulator, by introducing appropriate entries under the CRD IV/CRR package, only accelerated the implementation of this postulate. At some stage of development, cooperative banks have emerged as threats that should be neutralized by organizations selected from the cooperative banking sector [Bellver et al., 2011; Stern, 2014; Climent-Serrano, Pavía, 2015; Zygierewicz, 2015; Regnowski, 2017; Tuteja, 2017]. The creation of IPS systems lasted for over two years in Poland. Both associations of cooperative banks have created IPS structures to which most banks already belong. From among the 354 cooperative banks associated in the Bank Polskiej Spółdzielczości, there are 291 members of the Cooperative of the BPS Association. Several more banks have applied to the IPS. Selection is carried out in terms of risk to the group according to set criteria and an indicator system [Miętki, 2017]. In turn, in Spółdzielcza Grupa Bankowa, out of 202 associated banks, only seven do not belong to the Cooperative Protection System.

There are two essential functions of IPS systems: a system for detecting and diagnosing threats and a fund that provides support to the bank in a crisis. The system of protection through constant monitoring of the current situation of affiliated cooperative banks and the affiliation bank covered by the IPS system, as well as preventive and supporting activities planned under it, will ensure the support of its participants in terms of liquidity and solvency. It may also provide the necessary assistance in the event of non-standard situations occurring in any of the banks or system participants. Experience from Western countries shows that protection systems functioning for many years have contributed to strengthening the crisis resilience of banks that have decided to protect their future together. Today, there is no discussion about whether this form of mutual support is needed, but rather on how to improve it. Recent years have shown that it is difficult to predict the market situation, as exemplified by the 2007 subprime financial crisis.

Stricter prudential norms, which were originally intended only for large, internationally operating banks, ultimately need to be implemented in all European banks, including those operating locally, i.e. cooperative banks. This entails significant costs, especially in terms of meeting new, tightened liquidity standards. Banks that create 
a protection system have the option of meeting the short-term liquidity standard. Furthermore, the already obtained zero-weight permit for the mutual payments of IPS system participants allows the burden to be reduced related to new European regulations. The deviations from the general requirements obtained by the banks in the protection system also influence the reduction of capital requirements, which directly affects their ability to credit the economy.

The adopted sector self-control model is of importance for the effectiveness of IPS; on the one hand, the protection system is not an external supervisory institution but a cooperative whose members are individual banks, yet it is simultaneously a separate institution from an associating bank, which facilitates the exercise of the supervisory function without fear of succumbing to pressure [Miętki, 2017]. Confidence among IPS participants is based on quantifying the security level of everyone involved in the system, and this is what the system ensures. Effective self-control and the possibility of obtaining financial support are not the only benefits; a further advantage is the release of banks affiliated to IPS from the part of the mandatory contributions, paid to the KNF or the BFG. This benefit improves the banks' situation both in terms of capital and liquidity requirements. For example, associations of cooperative banks were authorized by the KNF to use zero-risk weights for exposures between IPS members.

IPS provides an additional level of security for bank branches in the event of a crisis - support is first granted from the system, due to which it is not necessary to apply for an NBP lombard loan, which would not be granted anyway to banks with solvency problems. Cooperative banks that are members of the system will also save considerable time due to the takeover by IPS co-operatives of some back-office tasks. Already, internal audits are carried out at banks by IPS cooperatives. There were, however, opinions that participation in IPS may limit the autonomy of acceding banks, and the system itself imposes far-reaching restrictions on banks; however, this is not true - although banks do have to bear financial costs. IPS is a security system, so it will not in any way engage in issues such as marketing or product offers.

Banks that have not chosen IPS must consider a much more meticulous surveillance activity, due to the fact that they do not have an effective tool for self-control. At present, in the cooperative banks that have joined the protection system, audits are conducted by auditors as an extension of the audit of the annual financial statements for the year preceding accession to the IPS system. The scope of the audit covers, in particular, the assessment of asset quality, i.e. the loan portfolio, and in some cases also debt securities. Such an audit was also carried out by the Bank Polskiej Spółdzielczości, which is very important, because it is the largest participant in the protection system [System ochrony Zrzeszenia ..., 2018]. Support mechanisms created within the framework of the protection system have been defined in the Act based on the functioning of cooperative banks, their association and associating banks. The implementation of the objective set before the system is possible because all participants have received funds from which financial assistance may be provided 
in cases of the risk of loss of liquidity or solvency of any participant. The protection system consists of liquidity support mechanisms based on mandatory deposit and solvency support mechanisms, which are themselves based on the aid fund which, in the BPS Association Protection System was named the Collateral Fund and in the second association was the Assistance Fund managed by IPS-SGB. This fund, which will eventually reach a value of approximately USD 100 million, will be mainly built from reduced bank contributions to the BFG.

Participants agreed to: apply common rules for risk classification and monitoring, inform each other about the risk incurred, and submit to preventive or sanctioned measures applied by IPS to those participants who take excessive risks. IPS managing societies, in addition to monitoring the risk of individual participants, also assess the risk of the system as a whole and are responsible for preparing the aggregated financial statements.

\section{Cooperative - BPS Association Protection System. A case study}

The aim of this paper is to demonstrate the specificity of tasks set for the BPS Protection System and their subsequent implementation in practice, conditioned by the financial capabilities of this IPS system.

The Cooperative - BPS Association Protection System (Spóldzielnia Systemu Ochrony Zrzeszenia BPS) functions as a unit managing the security system. Members of the cooperative in 2017 were an associating bank and 278 cooperative banks. The tasks of the analysed Cooperative - BPS Association Protection System include [Sprawozdanie z..., 2017]:

1. Implementation of internal audit in relation to members.

2. Monitoring, estimating and controlling the risk of members of a cooperative.

3. Conducting preventive, restructuring and application measures according to regulations.

4. Granting financial aid in the form and on the principles set out in the regulations.

5. Granting cash loans.

6. Providing guarantees and sureties.

7. Purchase and sale of monetary claims.

8. Taking up shares in cooperative banks or subscribing to bank shares affiliation.

9. Performing other tasks.

The membership fees for participation in the system amounted to PLN 9 million. In the case of 149 participants of the BPS System, the risk level was assessed as very low (global A), in 108 participants - as low (global B), in 21 participants as, including the Affiliating Bank, medium (global C); and in 1 participant - as higher (global D). The point scores of individual banks ranged from 1.15 to 4.17 . The economic potential of the cooperative - BPS Association Protection System is illustrated in Table 3. 
Pobrane z czasopisma Annales H - Oeconomia http://oeconomia.annales.umcs.pl Data: 26/04/2023 13:59:51

Table 3. Balance of the cooperative - BPS Association Protection System for 2017 in PLN

\begin{tabular}{|l|r|l|r|}
\hline \multicolumn{2}{|c|}{ Assets } & \multicolumn{2}{c|}{ Liabilities } \\
\hline Fixed assets & $199,853,180.00$ & Own fund & $2,420,977.68$ \\
I. Intangible and legal assets & $113,996.40$ & I. The basic fund & $720,000.00$ \\
- other intangible assets & $113,996.40$ & - share fund & $720,000.00$ \\
II. Property, plant and equipment & $85,856,780.00$ & II. Supplementary capital, including: & $825,000.00$ \\
1. Fixed assets & $44,504,180.00$ & - resource fund & $825,000.00$ \\
2. Fixed assets under construction & $41,352,600.00$ & III. Net profit & $875,977.68$ \\
III. Short-term financial assets & $351,270,404.28$ & B. Liabilities and provisions for & $349,504,637.58$ \\
IV. Short-term prepayments & $2,794.06$ & liabilities & $152,040.00$ \\
& & I. Provisions for liabilities & $349,326,693.58$ \\
& & II. Current liabilities & $344,948,496.49$ \\
& III. Special funds & $25,904.00$ \\
\hline Total assets & IV. Prepayments & $351,925,615.26$ \\
\hline
\end{tabular}

Source: Authors' own study on the basis of Sprawozdanie finansowe za rok 2016 r., Spółdzielnia Systemu Ochrony Zrzeszenia BPS, Warszawa 2017.

The guarantees granted by the Cooperative in the last period covered a guarantee for Bank Spółdzielczy in Łaszczów (for PLN 9.2 million) and a guarantee for Bank Spółdzielczy in Roźwienica (for PLN 8 million). The criteria for accepting a cooperative bank in the system are high. The individual minimum values for the accession criteria correspond to the minimum indicators and their values accepted by the BPS Protection System, as specified in the scoring principles [System, 2018]. Therefore, the adopted boundary values of quantitative indicators are presented in Table 4 .

Table 4. Indicators and marginal value concerning the BPS Association Protection System

\begin{tabular}{|c|l|c|}
\hline No. & \multicolumn{1}{|c|}{ Indicator } & Marginal value \\
\hline 1 & Tier 1 capital ratio & $\min 8 \%$ \\
\hline 2 & Total capital ratio & $\min 12 \%$ \\
\hline 3 & Asset quality indicator & $\max 5.5 \%$ \\
\hline 4 & Share of assets with a risk weight of up to 50\% in total assets & $\min 20 \%$ \\
\hline 5 & ROA net & $\min 0.3 \%$ \\
\hline 6 & C/I & $\max 75 \%$ \\
\hline 7 & Liquidity ratio of assets & $\min 7.5 \%$ \\
\hline 8 & Relation of loans to deposits & $\max 88 \%$ \\
\hline
\end{tabular}

Source: Authors' own study on the basis of Sprawozdanie finansowe za...

The development of this system and its economic strength (staying power) will depend on the further behaviour of cooperative banks. According to the vice-president of the Cooperative - BPS Association Protection System, Wiesław Żóltkowski, the banks are aware that they are responsible for the damage that one bank may cause [Ryzyko dla banków..., 2018]. They know that they should pay the depositors of the bank in the form of larger payments of funds to the BFG. It is already waiting for the security system to be watched, warned and repaired to prevent further bankruptcies. Banks are interested in watching each other and expect the protection system to do its 
job, eliminating threats by signalling them at the appropriate stage and implementing repair programs. Each bank would like other banks to be controlled, but usually wants itself to be controlled and supervised to a lesser extent. Nevertheless, this example of the IPS system may also affect the increase of clients' trust in those affiliated banks. However, measures should still be taken to increase both the capacity and the role of the Association of BPS Protection System.

\section{Conclusions}

Cooperative banks fulfil an important role in the local environment; they are an important supplement to the large equity bank sector. That is why, in Poland during the great crisis that engulfed this sector in the 1990s, the state gave them considerable support, despite the economic crisis and high inflation. Periodically increasing risk in the activities of cooperative banks justifies the costs they incur in the creation and operation of institutional protection systems; it is also in the interest of the clients of these banks and local communities. Belonging to the protection system can become an important factor when selecting a bank for potential clients who seek a reliable and predictable partner in running a business. It is necessary to convince the banks that IPS is not simply the next formal structure that has been imposed on them, but rather a system that may be helpful to them. All cooperative banks must be covered by this system. This may also affect the cooperative banking sector changes - such as their further concentration or changing business models. As part of the IPS system, a group repair plan has been developed, specifying how to respond to potential threats that may occur in banks. Thus, experts from the area of rehabilitation and bankruptcy of financial institutions should be involved in the operation of such systems. The IPS is new to Eastern Europe, and there is still a pressing need for scientific research into its functioning and improvement.

\section{References}

Bellver, J.A., Royo, R.E.C., Romero-Civera, A., New Spanish banking conglomerates. Application of the analytic hierarchy process $(A H P)$ to their market value, "International Research Journal of Finance and Economics" 2011, Vol. 78, pp. 71-82.

Climent-Serrano, S., Pavía, J.P., Determinants of profitability in Spanish financial institutions. Comparing aided and non-aided entities, "Journal of Business Economics and Management" 2015, Vol. 16(6), pp. 1170-1184. DOI: 10.3846/16111699.2013.801881.

Dec, P., Masiukiewicz, P., Aplikacja stress testów w bankowości, „Annales UMCS. Sectio H” 2012, Vol. 46(4), pp. 569-577.

Iwanicz-Drozdowska, M., Bezpieczeństwo rynku usług finansowych. Perspektywa Unii Europejskiej, Oficyna Wydawnicza SGH, Warszawa 2008.

Koleśnik, J., Institutional Protection Scheme w sektorze banków spółdzielczych w Polsce - modelowe rozwiązania, „Annales UMCS. Sectio H” 2013, Vol. 47(3), pp. 283-291. 
Masiukiewicz, P., Izmeneniya v sisteme finansovoy bezopasnosti, na primere Respubliki Pol’sha, «Izvestiya Irkutskoy gosudarstvennoy ekonomicheskoy akademii» 2014, No. 4, pp. 162-170.

Masiukiewicz, P., Management of Financial Safety Net in Poland, "Management Trends in Theory and Practice, Scientific Papers", Faculty of Management Science and Informatics, Institute of Management by University of Žilina 2013.

Miętki, Z., Instrumenty i mechanizmy wsparcia finansowego banków spółdzielczych, BODiE, Poznan 2017.

Ochocki, J., Banki spółdzielcze: IPS - i co dalej?, www.alebank.pl/banki-spoldzielcze-ips-i-co-dalej/?id=58608 [access: 14.08 .2016$]$.

Piechocka-Kałużna, A., Zalety $i$ wady wprowadzenia systemu ochrony w sektorze banków spótdzielczych $w$ Polsce, „Ruch Prawniczy, Ekonomiczny i Socjologiczny” 2017, nr 79(4).

Raport o sytuacji banków w 2017 r., KNF, Warszawa 2018.

Regnowski, P., Sytuacja finansowa polskich banków spótdzielczych w kontekście wprowadzenia pakietu CRR/CRD IV, „Przedsiębiorczość i Zarządzanie” 2017, nr 18(7), pp. 165-184.

Rolski, M., Banki spółdzielcze w Polsce - własność prywatna w stużbie spoleczności lokalnej czy przedsiębiorstwa nastawione na zysk?, „Prace Naukowe Uniwersytetu Ekonomicznego we Wrocławiu” 2015, nr 403, pp. 265-274.

Ryzyko dla banków spółdzielczych tkwi w ich mentalności, https://www.obserwatorfinansowy.pl/tematyka/bankowosc/najwieksze-ryzyka-dla-bankow-spoldzielczych-tkwi-w-ich-mentalnosci/ [access: 27.04.2018].

Sprawozdanie finansowe za rok 2016 r., Spółdzielnia Systemu Ochrony Zrzeszenia BPS, Warszawa 2017. Sprawozdanie z działalności Spółdzielni Systemu Ochrony Zrzeszenia BPS za 2016 r., Spółdzielnia Systemu Ochrony Zrzeszenia BPS, Warszawa 2017.

Stern, T., Regulating liquidity risks within institutional protection schemes, "Beijing Law Review" 2014, No. 5. DOI: 10.4236/blr.2014.53020.

System ochrony Zrzeszenia BPS, www.bankbps.pl/o-grupie-bps/system-ochrony-zrzeszenia-bps [access: 26.02.2018].

The First Global Crisis of the 21st Century, A. Felton, C. Reinhart (eds.), Centre for Economic Policy Research, London 2008, www.voxeu.org [access: 20.12.2016].

Tuteja, T., Rozwój i działanie banków spółdzielczych po wejściu w życie pakietu CRD IV/CRR. Szanse czy zagrożenia dla spółdzielczości bankowej?, [in:] S. Wieteska, I.D. Czechowska (red.), Granice finansów XXI wieku. Bankowość i ubezpieczenia, Wydawnictwo Uniwersytetu Łódzkiego, Łódź 2017. Zygierewicz, M., Dylematy zmian instytucjonalnych w polskim sektorze banków spótdzielczych w świetle nowych europejskich regulacji nadzorczych oraz wyników ekonomicznych sektora, „Annales UMCS. Sectio H" 2015, Vol. 48(4), pp. 275-290. DOI: 10.17951/h.2014.48.4.275.

\section{Model systemu ochrony instytucjonalnej (IPS) w polskich bankach spóldzielczych}

Artykuł dotyczy aktualnego i istotnego problemu zagrożenia bankructwem banków spółdzielczych w Polsce oraz opracowanego w tym kontekście modelu systemu ochrony instytucjonalnej (IPS) w polskich bankach spółdzielczych. Takie systemy zostały utworzone w dwóch stowarzyszeniach krajowych banków spółdzielczych jako spółdzielnie zarządzające programem ochrony instytucjonalnej (IPS). Zobowiązywały do tego również regulacje europejskie, w tym dyrektywa UE, poprzez wprowadzenie odpowiednich przepisów w ramach pakietu CRD IV/CRR. Celem autorów było potwierdzenie, czy system IPS znacząco poprawia bezpieczeństwo stowarzyszeń banków spółdzielczych i poszczególnych banków będących ich członkami. Podkreślono przy tym konieczność objęcia takim systemem wszystkich banków spółdzielczych, wówczas bowiem będzie możliwa całościowa analiza funkcjonowania takiego systemu, z uwzględnieniem jego głównych zalet i barier. Autorzy przeprowadzili własne studium przypadku oparte na Systemie Ochrony Zrzeszenia - BPS. 
Pobrane z czasopisma Annales H - Oeconomia http://oeconomia.annales.umcs.pl

Data: 26/04/2023 13:59:51

MODEL OF INSTITUTIONAL PROTECTION SCHEME IN POLISH COOPERATIVE BANKS

\section{Model of Institutional Protection Scheme in Polish Cooperative Banks}

This paper concerns the current issue of the threat of bankruptcy of cooperative banks in Poland and the model of the Institutional Protection Scheme (IPS) in Polish cooperative banks developed in this context. Such systems have been established in two associations of national cooperative banks as cooperatives managing the IPS. It was also influenced by European regulations, including the EU directive, through the introduction of appropriate provisions under the CRD IV/CRR package. The authors attempted to confirm that the IPS system significantly improves the security of associations of cooperative banks and individual banks. Since it is necessary to cover all cooperative banking with this system, the specificity of functioning of such a system is therefore analysed and its benefits and barriers were presented. The authors conducted their own case study based on the Cooperative - BPS Association Protection System. 